\title{
Sequestro e negligência como política de Estado: Experiências da segunda
} geração de atingidos pela hanseníase

Kidnapping and negligence as a State policy: Experiences of the second generation of those affected by hansen's disease

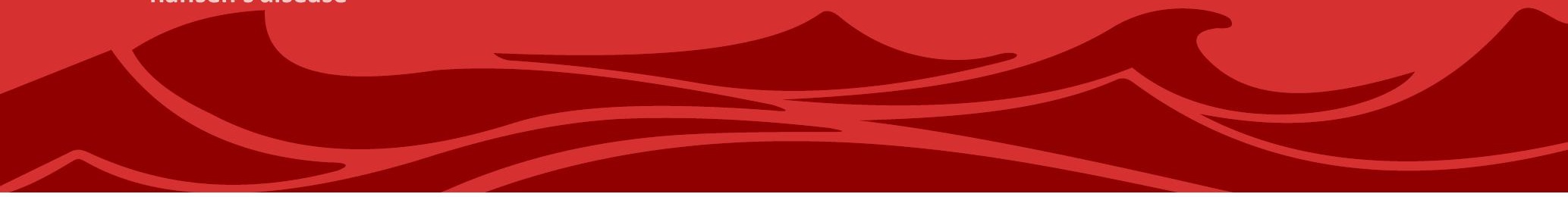

\section{Gláucia Maricato}

Doutoranda em Antropologia Social pela Universidade Federal do Rio Grande do Sul (PPGAS/UFRGS)

\section{Artur Custódio Moreira de Sousa}

Vice Coordenador nacional do Movimento de Reintegração das Pessoas Atingidas pela Hanseníase. Mestrando em Saúde Pública pela Escola Nacional de Saúde Pública - Fiocruz - RJ. E-mail:arturmorhan@gmail.com

\section{Resumo}

O presente artigo tem como objetivo analisar a experiência de familiares separados durante as políticas de isolamento compulsório das pessoas atingidas pela hanseníase no Brasil. Especificamente, busca-se refletir acerca dos trajetos e desafios enfrentados pelos filhos que foram separados dos pais isolados, além de lançar questões em torno das atuais políticas estatais de reparação daqueles sujeitos. Esse trabalho está baseado em dados etnográficos coletados ao longo dos últimos cinco anos junto a familiares e filhos, além de dialogar com fontes secundárias. Demonstramos a complexidade das experiências de separação, a forma como ela reverbera no presente e os desafios em face à burocracia do Estado quando o tema são as políticas reparatórias. Refletir sobre as experiências de separação compulsória da segunda geração de atingidos pela hanseníase pode lançar novas questões às atuais políticas estatais dirigidas a usuários de crack; ou seja, trata-se de um convite de aprendizado a partir das experiências do passado em busca de um futuro em que as políticas de Estado não violem os princípios básicos dos direitos humanos.

Palavras-chave: Hanseníase; Políticas públicas; Relações familiares; Direitos humanos.

\footnotetext{
Abstract

This paper aims to discuss the experience of families that were sundered apart by state policies of the mid-twentieth century that decreed the forced segregation of hansen's disease patients and the
} 
institutionalization of their children in Brazil. We will describe the challenges that the separated children have faced and we will reflect on the current state financial reparation sought for human rights violations of the first generation. This paper is based on five years of ethnographic fieldwork conducted with former interns, their separated children, and it engages with secondary sources. We show the complexities of the experiences of the separated children, their current struggles around these diverse experiences and the challenges they might

\section{Introdução}

Durante sessenta anos o Estado brasileiro ordenou e estimulou a internação e o isolamento de todas as pessoas atingidas pela hanseníase. Entre 1920 e 1980 milhares de pessoas seriam segregadas em colônias hospitalares, os então chamados leprosários, e milhares de crianças, filhos daqueles que estavam isolados, foram enviados para os chamados preventórios. Se milhares de pessoas foram segregadas devido à doença, também milhares de crianças foram retiradas do contato com seus pais e compulsoriamente institucionalizadas, entregues para a adoção formal e informal, além de muitas que tiveram um destino diferente, circulando entre casas de familiares, conhecidos e vizinhos.

Tratava-se de uma política higienista inspirada no modelo europeu que defendia a intervenção na vida da população como solução para questões de saúde - ou seja, a higienização vinha como um mecanismo de regulação, controle e vigilância da população. Conforme face to facilitate claims to financial reparation from the Brazilian state. As we see, a reflection on the experiences of the second generation of people affected by the forced segregations may raise new questions about the current Brazilian state responses to substance abuse and its human rights violations. We argue that looking toward the future, we should learn from the past.

Keywords: Hansen's disease; Public policies; Family relations; Human rights.

diversos pesquisadores já demonstraram, ${ }^{1,2,3,4}$ a 'redescoberta' da doença pelo chamado mundo ocidental ao final do século XIX e início do século $X X$, e o modelo segregacionista que foi mundialmente estimulado a partir de então, estava diretamente relacionado com a empreitada imperial e colonialista dos países do norte global; leia-se, EUA e Europa ocidental. Em sincronia com o cenário internacional, a Primeira Conferência Americana de Lepra, realizada em 1922, no Rio de Janeiro, chegaria a conclusão de que o isolamento dos doentes e a separação de seus filhos era a única maneira de combater e controlar a doença. ${ }^{5}$ Durante décadas o isolamento e a separação dos filhos foram recomendados nacional e internacionalmente por autoridades científicas e políticas da época. Em sincronia com esse cenário, já em 1923 entraria em vigor a primeira legislação brasileira que dispunha sobre o tema. Esse modelo era reforçado a cada nova Conferência Internacional sobre Lepra, o maior evento sobre o tema daquele momento. Ainda 
que seja possível rastrear alguns médicocientistas que se opuseram ao isolamento durante aqueles eventos, naquela altura a política de isolamento já havia ganhado ares de legitimidade, tratada como a única solução possível; como se fosse o único modelo de intervenção que se poderia oferecer.

Foi apenas em meados da década de cinquenta, exatamente em 1958, que a comunidade científica internacional condenaria pela primeira vez o sistema de isolamento e separação. Desde meados da década de quarenta, quando foi descoberta a ação das sulfonas no tratamento da doença, falava-se na descontinuidade das internações em função da não contagiosidade dos pacientes tratados. No entanto, sabe-se que as políticas de segregação compulsória dos pacientes atingidos pela hanseníase e a separação de seus filhos se associava a outros fatores para além do controle do contágio. Concepções cristãs, imaginários populares e discursos científicos se entrelaçavam na criação de medo e rechaço quando o assunto era lepra. Preconceito e estigmas jogavam um papel importante na definição das políticas estatais voltadas aqueles sujeitos, fazendo com que a segregação se tornasse legitima e desejada por parte da população dita sadia e pelas autoridades que buscavam apoio popular.

$\mathrm{Na}$ esteira do cenário mundial,com a descontinuidade da política isolacionista, uma nova legislação nacional definiria o direito à alta para determinados pacientes em 1962 e, em seguida, uma portaria de 1976 do Ministério da Saúde finalmente decretaria o final das políticas de segregação.Todavia, conforme se sabe, na prática o isolamento dos doentes e a separação dos filhos dos internos seguiria ocorrendo até finais de $1980 .{ }^{6}$ Ou seja, a despeito da legislação, a descontinuidade do modelo segregatório se daria de maneira paulatina e diversificada de acordo com cada região e localidade. Além disso, o desmantelamento do modelo segregacionista não foi acompanhado por nenhuma política federal de apoio aqueles que eram desinstitucionalizados. Impulsionados a deixar as colônias em que tinham passado décadas, os pacientes foram deixados à própria sorte na reformulação de suas vidas do outro lado daqueles muros.

Há dez anos atrás, em setembro de 2007,0 então presidente Luiz Inácio Lula da Silva aprovaria uma lei federal que concederia o direito à reparação estatal a todos os sujeitos que foram compulsoriamente isolados em colônias hospitalares até dezembro de 1986. Ao fazê-lo, o Brasil se tornaria o segundo país do mundo a indenizar os atingidos pela hanseníase, após o Japão que havia aprovado medida similar em 2001. Desde a aprovação daquela política, a segunda geração de pessoas atingidas pelas medidas de isolamento, os filhos que foram separados, também clamam por uma reparação do Estado.Desde 2011 corre um Projeto de Lei que visa estender o direito à reparação estatal também ao movimento que ficou conhecido como Filhos Separados.Conforme justificativa do projeto, 
quando o Estado obrigou as pessoas atingidas pela hanseníase a viverem isolados ele" prejudicou os filhos desses doentes, não só no que tange ao aspecto emocional e psicológico, mas também no aspecto econômico, já que eram os genitores que garantiam o sustento (...) $)^{\prime \prime: 3} \mathrm{O}$ atual movimento político dos filhos separados busca tanto uma reparação moral e financeira pela violação de seus direitos, como também vêm solicitando o direito à políticas de acesso a tratamento psicológico. Em 2013, o governo federal havia anunciado que estava na ordem do dia a aprovação de uma medida reparatória. Entretanto, os últimos eventos que marcaram a política nacional deixam pouco espaço para a esperança de que esse direito seja reconhecido num futuro próximo. A luta dos atingidos pela hanseníase por uma cidadania que seja plena remonta ao período de redemocratização do país na década de oitenta, quando foi criado o Movimento de Reintegração das Pessoas Atingidas pela Hanseníase (Morhan). Desde então, esse movimento tem crescido e desenvolvido diferentes frentes de atuação. Não será agora que suas vozes irão ser caladas.

O presente artigo faz parte das pesquisas em andamento de mestrado e doutorado da autora. A metodologia adotada lança mão de técnicas etnográficas de coleta de dados. Durante a pesquisa de campo, levamos à cabo entrevistas abertas e semi estruturadas com exinternos de colônias hospitalares e os filhos que foram separados, realizamos observação participante (contato prolongado com participação na rotina cotidiana) e pesquisa em documentos e fontes secundárias (tais como matérias de jornais, projetos de lei, etc.). Ao longo do trabalho de campo, os sujeitos eram convidados a participar da pesquisa e narrar acerca de suas trajetórias de forma individual ou junto a seus familiares.

A presente pesquisa não foi submetida à comitê de ética, mas está inteiramente de acordo com os princípios básicos do Código de Ética da Associação Brasileira de Antropologia (ABA). Também em concordância com o referido código de ética, e em sincronia com os debates acerca dos limites do modelo legalista de consentimento, ${ }^{8,9}$ não utilizamos os termos de consentimento livre e esclarecido. Durante nossa inserção a campo, optamos pela obtenção do consentimento oral dos participantes - sempre deixando claro para os mesmos os objetivos da pesquisa, incluindo uma descrição da história, contexto e tema.

O presente artigo está subdivido em dois momentos. A seguir, iremos adentrar entrevistas realizadas com filhos que foram separados e familiares. Nesse primeiro momento, iremos apresentar quatro trajetórias distintas da segunda geração de atingidos pela hanseníase. Através das experiências de Dona Arlene, Bebete, os irmãos Janino e Leon, e outros quatro irmãos, vamos refletir acerca da complexidade e da diversidade de experiências, trajetos e questões que esses casos provocam.O objetivo específico é apontar para a maneira como uma futura política de 
reparação para os filhos que foram separados e familiares precisaria estar inteiramente atenta as complexidades dessas trajetórias, dado que a depender do enquadramento ou das exigências colocadas, determinados sujeitos poderiam vir a ser excluídos de receber o seu direito reparatório.

No segundo momento desse artigo, essa questão se torna ainda mais evidente dado que iremos descrever a parceria estabelecida entre o movimento social e uma equipe de geneticistas. A partir da experiência acumulada dos ex-internos diante das exigências burocráticas da política reparatória conquistada em 2007, o movimento social passou a prever que, caso aprovada uma reparação também aos filhos separados, o estado brasileiro iria requerer provas do vínculo familiar entre pais e filhos separados - algo que muitos deles, por diversas razões, não teriam como oferecer. A parceria com a equipe de geneticistassurgiu como uma possibilidadedeproduçãode provas do vínculo biológico. Nesse segundo momento, nosso objetivo será demonstrar, em diálogo com os casos apresentados anteriormente, como os testes de DNA poderiam se deparar com limites bem demarcados nesse contexto.Iremos sublinhar a maneira como essa tecnologia de identificação dependeria de uma série de outros elementos para a produção das referidas provas e, em muitos casos, tais elementos não estariamdisponíveis.

Acreditamos que a presente reflexão em torno da demanda por justiça da segunda geração de atingidos pela hanseníase pode lançar questões e aprofundar o debate atual acerca da chamada política anti-crack. Essa política tem dado espaço para que autoridades locais decidam sobre o futuro de milhares de crianças, filhos de mães usuárias de droga e em situação de vulnerabilidade. Sugerimos que aatual política de crack encontra muitas similaridades com o modelo autoritário, e contrário aos direitos humanos, empregado décadas atrás com a segunda geração de atingidos pela hanseníase.

Nosso objetivo final é suscitar uma reflexão acerca das violações dos direitos humanos implicadas nas políticas de Estado. Trazer para o primeiro plano os dramáticos efeitos contemporâneos das escolhas autoritárias e discriminatórias do passado, e colocando-as, ao final, em paralelo com o modelo da política anti-crack, irá nos auxiliar a sublinhar a maneira com que, ao mesmo tempo em que o Estado brasileiro teria reconhecido os erros do passado junto aos atingidos pela hanseníase, ele estaria levando adiante uma política de separações contrária aos princípios básicos de justiça social e cidadania.

Separações: cicatrizes, suspeitas e a busca pelas famílias biológicas

Dona Arlene tinha cinco anos quando foi viver junto com seus outros três irmãos no preventório - espécie de orfanato para os filhos das pessoas isoladas. Assim que o seu pai foi diagnosticado com a hanseníase, o médico 
responsável logo avisou que ele seria enviado para o isolamento e que seus filhos deveriam ficar por um período de quarenta dias no preventório. Conforme previsto, o pai foi logo internado na ex-colônia de Souza Araújo, em Rio Branco, capital do Acre.Apesar da mãe não estar doente, não foi permitido que os filhos ficassem com ela e foram todos enviados para o preventório da capital acreana onde moravam.

Naquela altura a mãe das crianças não tinha nenhuma ideia de que aqueles quarenta dias de quarentena se tornariam dez anos de separação. Quando ela retornou ao preventório após o período estipulado para buscá-los, foi surpreendida com a informação de que eles não seriam liberados. Quando entrevistada em agosto de 2012, na cidade de Rio Branco, Dona Arlene apenas diria que "tudo tinha sido uma enganação". A mãe de Arlene tinha recebido a informação de que as crianças ficariam em quarentena para realizar um acompanhamento, envolvendo a aplicação de medicação em função do contato com o pai doente. No entanto, ao final daquele período as crianças não foram liberadas e Arlene e seus irmãos permaneceriam até a adolescência naquela instituição, onde poderiam receber a visita da mãe durante apenas uma única hora aos domingos.

Tal como a maioria daquelas instituições no país, o preventório que Dona Arlene passaria a infância e começo da adolescência era administrado por uma irmandade católica. Em torno de cinquenta anos, à época da entrevista, Dona Arlene lembra que "as irmãs" eram responsáveis pelo gerenciamento do preventório. As tarefas diárias, tal como cozinhar, limpar e cuidar das crianças pequenas ficava sob responsabilidade daquelas crianças que já eram mais velhas. $A$ instituição contava com um galpão para meninas, um para os meninos e um berçário, e havia desde recémnascidos até aqueles que estavam para completar dezoito anos (quando eram liberados). Aos onze anos a pequena Arlene já era a responsável por receber os recémnascidos que vinham direto da ex-colônia hospitalar. Conforme lembra, "eu tinha que cuidar das crianças que chegavam lá da excolônia Souza-Araújo ainda enroladas só em trapos e cortado só o cordão umbilical. Era eu quem dava o primeiro banho e fazia o mingau".

Tal como diversos outros filhos separados vêm apontando nos últimos anos, Dona Arlene também relatou diferentes formas de abuso que sofreu no interior do preventório. Ela apontou para castigos que as irmãs criavam incluindo ficar sem comida ou ajoelhar durante longo períodos de tempo sobre feijão ou milho -, e enfatizou o trabalho que teria de cuidar de uma outra garota, bem mais jovem do que ela, e que sofria com paralisia. Ademais, entre as experiências elencadas por Dona Arlene, também entraria um relato sobre abuso sexual por parte de outros internos; algo que tem se verificado comum entre as filhas que foram separadas. 
Aos poucos, viver no preventório se tornaria um fardo. Aos quinze anos, Arlene enfrentaria a perda do irmão mais novo num acidente. Segundo Dona Arlene, aquele teria sido um momento crucial para ela e os outros dois irmãos que estavam no preventório. Na esteira daquele evento, eles passaram a planejar e a ameaçar a administração de que estavam planejando uma fuga. Foi nesse momento que Dona Arlene e os dois irmãos finalmente seriam liberados pela administração da instituição e voltariam para a casa de sua mãe e do então padrasto dez anos depois. O pai jamais sairia da colônia.

Histórias como as de Dona Arlene, cheia de episódios de violência, abuso de poder e negligência, povoam as narrativas daqueles que viveram nessas instituições estatais. ${ }^{10} E$ necessário pontuar que, ainda que os casos sejam muitos, nem todos os relatos sobre os preventórios estão marcados por violência e abuso. A busca pela reparação dos filhos separados está baseada na violação cometida pela compulsoriedade da própria separação. Além disso, cabe pontuar que nem todas as crianças tiveram a oportunidade de retornar aos seus familiares e, muitas delas, separadas e adotadas ainda crianças, jamais descobriram suas origens familiares.

Esse é o caso de Bebete Maria. Após deixar o preventório com dezoito anos, e sem contar com nenhum suporte, ela passaria a viver nas ruas. Durante nossa entrevista, ela não mencionaria qualquer história acerca de seus pais, mas passaria todo o tempo explicando sobre a relação que ela mantinha com a família de sua irmã já falecida. Uma relação que, conforme iríamos descobrir, estava profundamente marcada por diferenças de classe. Bebete, um irmão e uma irmã foram enviadas ao preventório ainda pequenos. Bebete jamais voltaria a ver o irmão mais velho que teria fugido ainda pequeno da instituição. Já a sua irmã mais nova teria sido logo adotada pela família "daquela juíza famosa daqui" citando o nome de uma família rica e conhecida da capital onde vivia. Bebete enfatizou como aos dezoito anos foi liberada do preventório. Naquela altura, não tinha nenhuma notícia do irmão, tampouco tinha mantido contato com a irmã. A saída do preventório seria marcada pelo total desamparo. Sem ter ninguém a quem recorrer por qualquer auxílio, hospedagem ou trabalho, aos poucos ela se encontraria numa situação de extrema vulnerabilidade, vivendo nas ruas onde, com emoção, enfatizaria que comeu "lixo, que fazia de tudo, menos vender meu corpo pra homem". Sem nenhuma política de inclusão ou auxílio aos filhos que cresceram naquelas instituições, e muitas vezes sem acesso nem mesmo a educação básica, encontrar a porta da rua aberta em um contexto de poucas oportunidades era uma tarefa de sobrevivência.

Durante a entrevista, Bebete chamou a atenção para a dificuldade que estava vivendo naquele momento. Fazia poucos anos que a irmã, então com seus cinquenta anos, teria cometido suicídio. Segundo ela, os três filhos da irmã 
jamais a tinham reconhecido como tia, apesar dela referir-se a eles como sobrinhos. A relação entre ela e a família da irmã deixava claro as tensões em torno das diferenças de classe social. De um lado, os três filhos da irmã, então já adultos, faziam parte da elite da cidade. De outro, Bebete recebia ajuda de um programa social para pagar o aluguel de uma kitnet. Bebete resumiu sua relação com aqueles que ela chamava de sobrinhos dizendo que a única ocasião em que eles se viam era quando ela fazia uma visita à casa da família e o ex-marido da irmã lhe dava dez reais.

Casos como de Arlene e Bebete nos ajudam a compreender a maneira como o Estado, em nome do bem-estar daquelas crianças, acabou produzindo situações de extrema violência, preconceito e negligência social. A mãe de Dona Arlene, que quando deixou seus filhos no preventório voltou para casa com a informação de que os buscaria pouco mais de um mês depois, viveria a angústia de voltar para casa sozinha sem que jamais tenham lhe dado qualquer explicação satisfatória. As regras não eram claras - ou se fossem, não eram de conhecimento daquelas pessoas, e tampouco eram colocadas em prática pelas instituições que se diziam representar o interesse do Estado. Bebete também passaria toda a infância e a adolescência no preventório trabalhando na limpeza, na cozinha e nos cuidados de outras crianças, e aos dezoito anos não encontraria qualquer política que pudesse auxiliar a sua transição para fora do preventório.
Os casos falam sobre uma filha separada que, de certa forma, conseguiu retomar sua família Dona Arlene -e sobre uma filha que, frente a toda as relações de poder envolvidas, conseguiu manter o conhecimento do paradeiro de uma irmã - Bebete. A experiência de Arlene e Bebete, entretanto, não podem ser tomadas como representantes das experiências dos filhos separados. Ainda que essas trajetórias tenham pontos de similaridade, elas também se diferenciam. Desde que o Morhan passou a reivindicar uma política de reparação aos filhos separados, abrindo diferentes frentes de luta por aquele direito, diversas histórias de famílias que se reencontraram depois de décadas vieram à tona, foram impulsionadas e ganharam publicidade. Não estamos sugerindo que cada caso seria um caso, mas que é necessário estar atento a complexidade das diversas experiências.

Podemos trazer à tona o caso dos irmãos Janine e Leon, filhos de pacientes que foram isolados numa colônia no Pará, que à época ainda crianças foram levados para o Suriname por um hansenólogo que trabalhava na região e foram adotados por ele como se fossem seus filhos biológicos. Anos depois, já na adolescência, a família do hansenólogo se mudaria para a Holanda. Com a ajuda do Morhan, em abril de 2017, em torno de cinquenta anos depois da separação, Leon e Janine vieram ao Brasil pela primeira vez e se encontraram em Belém do Pará com irmãos biológicos que não conheciam e outros familiares, além de realizarem uma visita a ex-colônia paraense onde nasceram. Há 
anos os irmãos vinham buscando encontrar pistas pelas redes sociais, e esse desfecho só foi possível dado que os pais adotivos guardaram informações que auxiliaram os irmãos em sua busca pela história de sua família biológica. A história de Leon e Janine é apenas mais uma entre tantos reencontros que vêm acontecendo nos últimos anos. E como veremos, a seguir, elas também têm possibilitado pessoas revisitarem o seu passado.

André, Leandro, Lilian e Viviane eram quatro de nove irmãos do interior do estado do Rio Grande do Sul. Tanto o pai quanto a mãe dos irmãos tinha vivido na ex-colônia de Itapuã, a 60 km da capital daquele estado.As diversas reportagens e reencontros emocionantes que vinham sendo publicizados pela mídia tinham despertado uma suspeita na família. Conforme os irmãos nos contariam, sua mãe tinha dado à luz a um de seus irmãos no interior da ex-colônia. Horas depois do parto, já de volta ao seu quarto, a mãe receberia a visita de alguém da enfermaria dizendo que o bebê tinha falecido.

Aquilo que intrigava os irmãos era o fato da mãe ter dito várias vezes que eles nunca deixaram ela ver o corpo do bebê e, tampouco, tinha recebido alguma certidão de óbito ou documentação sobre a morte do filho. Ao saber de histórias de reencontro, tal como aquela dos irmãos que foram levados para a Europa, eles passariam a questionar se a criança, na verdade,não poderia ter sido levada clandestinamente para adoção. Conforme Viviane, "a suspeita é que ele possa estar vivo, porque naquela época, isso foi em setembro de 1957, era costume dar as crianças do orfanato da colônia". Lilian também acrescentou que se lembrava de um episódio da sua infância no preventório, quando uma mulher apareceu querendo ficar com ela. Ela era muito pequena na época para se lembrar da mulher, mas tinha bem claro na sua memória quando sua mãe lhe contou sobre essa história anos depois.

A seguir, iremos tratar da experiência da política reparatória da primeira geração de atingidos pela hanseníase (aqueles que foram isolados) e de um acordo de cooperação que foi assinado entre o Morhan e uma equipe de geneticistas. Essa parceria foi estabelecida na esteira da luta do movimento por estender a reparação também para a segunda geração (os filhos separados). A proposta era realizar testes de DNA entre filhos separados e seus pais que foram internados afim de criar provas do vínculo biológico entre aqueles sujeitos e, assim, permitir que, caso a reparação fosse concedida, eles tivessem os resultados do DNA como provas do vínculo (e, portanto, da separação). Iremos realizar um paralelo com as trajetórias que acabamos de tratar e, assim, demonstrar os limites dos testes de DNA nesse contexto enquanto tecnologia de identificação.Dessa forma, buscamos avançar nosso argumento acerca da necessidade das políticas reparatórias estarem atentas à diversidade de trajetória dos sujeitos, ampliando as possibilidades de comprovação da separação. 
Tecnologias do reencontro: parcerias, desafios e limites

Conforme já mencionado, há pelo menos dez anos o movimento dos atingidos pela hanseníase vêm buscando estender as políticas de reparação concedidas aos ex-internos também aos filhos que foram separados. Logo nos primeiros anos após o surgimento desse pleito político, os ativistas estavam conscientes do enorme desafio que teriam pela frente. Estava em jogo não apenas o desafio de colocar essa pauta na agenda da política nacional, mas de encontrar maneiras de comprovar o vínculo entre ex-internos e os filhos separados que não foram registrados no nome de seus pais biológicos isolados.

Após a aprovação da política de reparação em 2007, os ex-internos de colônias hospitalares se viram em meio a uma verdadeira corrida em busca de papéis. A lei 11.520/2007 que concedeu o direito à pensão mensal vitalícia ao ex-internos geraria, na prática, a obrigatoriedade de comprovação do isolamento nas ex-colônias hospitalares. Isso significava encontrar algum documento nos arquivos empoeirados de velhas instituições que indicasse que o sujeito tivesse sido internado naquela instituição. Existem hoje em torno de vinte e seis ex-colônias no país que contam com moradores da época do isolamento e que agora se transformaram em hospitais de referência em hanseníase, centro de dermatologia ou,infelizmente,estão em ruínas - entre as pautas do movimento, está a preservação desses espaços enquanto patrimônio da história nacional.

De uma hora para outra, dezenas de hospitais espalhados por todo o país passaram a receber ofícios da Secretaria de Direitos Humanos da Presidência da República, à qual estava vinculada a comissão responsável pela análise dos pedidos de reparação, solicitando a ficha de registro e de acompanhamento de pacientes que tinham passado por aquelas instituições cinquenta, sessenta ou mesmo oitenta anos atrás. Aos poucos, ativistas dos núcleos estaduais do Morhan e ex-internos passaram a organizar e auxiliar a administração dessas instituições a buscar e separar arquivos que pudessem servir de prova no requerimento de ex-internos.Muitos pedidos levaram anos até serem aprovados, outros não tiveram a mesma sorte e foram negados por falta de provas documentais.

Os atingidos pela hanseníase e os filhos separados sabiam que uma vez aprovada uma medida indenizatória à segunda geração que sofreu com as políticas segregatórias, o Estado passaria a exigir provas da separação para a concessão daquele direito. Ou seja, eles passaram a prever que a mesma exigência realizada à primeira geração iria ocorrer com a segunda geração caso conquistassem o direito a reparação estatal. Aquele mesmo Estado que havia organizado e autorizado as separações e negligenciado centenas de crianças em nome de seu bem-estar, passaria então a exigir provas documentais -pressupondo que as antigas 
colônias e os preventórios tivessem mantido arquivos bem organizados com o nome das crianças e suas origens, o que de fato não ocorreu na maioria delas. Os ex-internos sofreram com o isolamento e, em seguida, com a impossibilidade de acessarem seu direito de reparação por ausência de arquivos que pudessem comprovar a sua institucionalização.

Os ativistas sabiam que enfrentariam a rigidez de um sistema burocrático fundamentado em papéis (que talvez nunca tenham sido produzidos ou que tiveram diversos destinos).Além disso, na prática, a adoção por outras famílias representa apenas uma das razões pelas quais aqueles sujeitos não tinham documentos que comprovassem o vínculo com seus pais que foram internados. Não é difícil encontrar uma variedade de casos. Em entrevistas com diversos filhos, encontramos mais de um caso em que a criança não foi registrada no nome dos pais internados para evitar o preconceito da época de ser identificada como filhos de internos. É também comum encontrar crianças que ficaram com as mães quando os pais foram internados. Décadas atrás o registro civil não era um documento retirado logo após o nascimento. Muitas das crianças que ficaram com a mãe seriam registradas anos depois quando em face da necessidade de algum documento (como para a matrícula da escola, para alistamento militar, para conseguir trabalho e etc.). Dessa forma, aquele pai que apareceria no registro,muitas vezes não era o pai biológico, mas aquele que tinha assumido a responsabilidade na criação; ou seja, muitos dos filhos separados foram registrados no nome dos pais de criação ou,às vezes, apenas no nome da mãe (ou no nome das mães de criação, etc.).

Também houve casos de bebês que nasceram dentro das colônias e a família conseguiu fazer um acordo com a administração da instituição para mandar a criança para os cuidados de algum familiar - há, por exemplo, uma família que relatou que teria conseguido o apoio de um guarda da ex-colônia para, na surdina, entregar a criança para um vizinho. Portanto, há famílias que conseguiram resistir ao envio das crianças para os preventórios onde eles sabiam que elas poderiam ser entregues a adoção formal ou informal - essa última, aquela adoção em que a família adotiva registra a criança como se fosse um filho biológico (apagando a história das origens das crianças, e muitas vezes impossibilitando que, no futuro, caso assim desejem, elas possam encontrar seus pais biológicos). É claro que nem sempre encontrar um lar provisório para os filhos com algum conhecido ou vizinho tenha significado estar livre de formas de violência; várias dessas crianças sofriam preconceito dentro de suas famílias de criação como "filhos de leprosos" e eram tratadas como uma visita indesejada que precisavam trabalhar dentro de casa para pagar sua estadia. Em todo caso, todos esses casos têm algo em comum: são filhos separados de pais internados durante as políticas de segregação que não possuem documentos de identificação que comprovem esse vínculo. 
Em 2011, inspirados no caso das Madres de La Plaza de Mayo da Argentina,o Morhan assinou um acordo de cooperação com o Instituto Nacional de Genética Médica PopulacionalINaGeMP. ${ }^{11} \mathrm{O}$ objetivo era produzir provas do vínculo biológico através de exames de DNA. Por um lado, o Morhan ficaria responsável por identificar e organizar a lista daqueles que não tinham documentos que comprovassem o vínculo com os pais que foram internados e interessados em realizar os testes. Por outro lado, a equipe de geneticistas do INaGeMP ficava responsável por coletar as amostras de material genético, realizar os testes de DNA e entregar os resultados aos interessados. Essa aliança ficaria conhecida como Projeto Reencontro. ${ }^{12}$

Entre agosto de 2011 e dezembro de 2015, a equipe de geneticistas coletou amostras de material genético de 441 indivíduos em onze estados brasileiros. Entre esses indivíduos, $63,4 \%$ tinha sido separado dos pais logo após o nascimento, sendo que a adoção informal ocorreu em $54,8 \%$ desses casos. Desse total,15,2\% das amostras foram destinadas ao chamado "banco". Isso significa dizer que os outros $84,8 \%$ eram casos em que os indivíduos que procuraram o Projeto Reencontro junto com a mãe, pai ou irmão com quem iriam fazer o teste de DNA. Ou seja, eram casos em que suspeitavam do vínculo e queriam testar ou casos em que o contato havia sido mantido, mas os sujeitos não tinham provas documentais do vínculo biológico. ${ }^{13}$

Podemos retomar os casos que vimos anteriormente para entender melhor essa questão. Por exemplo, Dona Arlene (aquela que ficou no preventório com os irmãos e retornou à casa de sua mãe após ameaçar uma fuga), não faz parte dos mais de quatrocentos indivíduos que compõe o projeto. Ela tinha o registro no nome dos pais biológicos e, portanto, caso venha a requerer uma indenização ao Estado, poderia utilizar tais documentos como prova do vínculo. De forma bem diferente, temos o caso de Leon e Janine (os irmãos que foram enviadas à Europa e registrados como filhos biológicos dos pais adotivos). Nesse caso, os pais adotivos não tinham apagado o passado das crianças, mas guardaram os documentos e informações que auxiliaram os irmãos a encontrar sua família biológica cinquenta anos depois. Portanto, ainda que os irmãos não tenham sido registrados pelos pais biológicos, possuem outros documentos que poderiam servir na comprovação da separação. Já o caso que vimos dos quatro irmãos do Rio Grande do Sul é bem diferente. Eles fazem parte daqueles $15,2 \%$ que estão no "banco". Ou seja, o material genético de um dos irmãos foi armazenado pela equipe de geneticistas e poderá ser utilizado se algum dia eles encontrarem algum suspeito de ser aquele irmão dado como morto décadas atrás. Uma das tarefas do Morhan é auxiliar nesses casos, mas é preciso ter em mente que os membros do Morhan são ativistas voluntários e que não se trata de nenhuma organização especializada em encontrar desaparecidos. Eles trabalham com a esperança de fazer justiça, mas também sabem que aquilo que buscam pode vir a ser uma agulha no palheiro. 
Por último, temos a história de Bebete (aquela que ficou no preventório até os dezoito anos, enquanto a irmã foi adotada e o irmão fugiu). Nesse caso, sabemos que ela não possui o registro no nome dos pais biológicos internados e que ela havia mantido contato com a família da irmã. Ela poderia buscar algum registro no preventório aonde esteve internada, no entanto, caso eles existam, nunca foram divulgados pelas organizações que tomam contam desses arquivos.Outra possibilidade na busca por documentação seria comprovar o parentesco biológico com seus pais isolados através da família da irmã (ou seja, um teste de DNA para verificar uma relação do tipo tiasobrinhos, algo que a equipe de geneticistas também já vinha realizando em outros casos). Entretanto, isso apenas seria possível caso a família da irmã de Bebete tenha guardado alguma prova das origens familiares do bebê adotado. Em caso positivo,ela poderia realizar um teste de DNA com os sobrinhos e, através daquele resultado, estabelecer uma probabilidade de parentesco com a irmã, criando, portanto, uma prova da filiação. Ainda que seja possível que a família da irmã de Bebete tenha registros documentais das origens do bebê adotado, tal como no caso dos irmãos europeus, Bebete teria que enfrentar um obstáculo que parece ainda mais complexo.A entrevista realizada com ela aconteceu em um dos eventos do Projeto Reencontro quando ela nos procurou e de forma desesperada contou que a família da irmã jamais iria concordar em realizar os testes de DNA; como falou, aqueles que ela chamava de sobrinhos não lhe reconheciam comotia.

Os exames de DNA entraram como grande aliado desse movimento, no entanto as relações de parentesco, as complexidades das relações sociais e as suas dinâmicas colocam limites bem demarcados a essa tecnologia de identificação.O caso de Bebete nos auxilia a perceber essa questão. Além disso, os testes de DNA atuam na produção de dados sobre vínculos biológicos entre os indivíduos e, tal como se sabe, relações de parentesco não se fundamentam em relações biológicas (ainda que se complementem). Isso significa dizer, por exemplo, que há um limite bem claro na atuação dos exames quando o filho que foi separado dos pais no momento do isolamento em ex-colônia tinha sido originalmente adotado. Ou seja, os testes de DNA serão incapazes de comprar o parentesco entre aqueles filhos que foram, sim, separados de seus pais pelas políticas de internação (mas que não eram filhos biológicos, mas de criação). Entre os ativistas que lutam pela causa dos filhos separados, existe o caso de um filho que foi separado dos seus pais adotivos. Portanto, não podemos perder de visa que essa tecnologia de identificação possui seus limites e que as experiências são múltiplas e complexas.

Conclusão: Reparar o passado também é modificar o presente

Os atingidos pela hanseníase estão buscando todas as ferramentas que possam Ihes auxiliar na busca por justiça. Aquilo que deveríamos nos 
questionar é a responsabilidade do Estado pelas separações, como também pelas diversas maneiras com que atuou apagando a história daquelas crianças e, muitas vezes, impedindo que possam identificar suas famílias biológicas. Acreditamos que a reflexão acerca das consequências daquela política autoritária de separação nos auxilia a imaginar e desenvolver futuras políticas fundamentadas nos direitos humanos, incluindo o direito ao conhecimento de suas origens.

Quando colocamos a experiência dos Filhos Separados lado a lado com as atuais políticas de adoção compulsória de filhos de dependentes químicos no Brasil, podemos questionar: quais são as formas de discriminação, de relações de poder, de hierarquias de classe, raça e de etnia que estão atualmente informando a organização e gestão desse modelo? Conforme apontam pesquisadores, a atual campanha de separação compulsória de mães em situação de vulnerabilidade, como por exemplo as usuárias de drogas ou em situação de rua, de seus filhos, caminha na contramão daquilo que deveríamos ter subtraído da experiência passada de violações dos direitos humanos. ${ }^{14}$

Não se trata de cruzar os braços aos usuários de drogas e aos seus filhos, mas de repensar a forma com a qual lidamos com essa questão, fitando em específico as desigualdades e violações de direitos que operam no interior do modelo atualmente empregado. A guarda do Estado jamais demonstrou ser melhor do que a mão da família e, muitas vezes, o discurso do bem-estar das crianças que são arrancadas de seus pais responde antes de mais nada a noções de hierarquias e categorias exteriores de cuidado e proteção. Podemos nos questionar: até que ponto essa intervenção não está respondendo a anseios sociais baseados em formas de discriminação e, nessa esteira, se torna capaz de encontrar qualquer razão para julgar aquelas mães e pais como incapazes de criar os próprios filhos? A política de separação atua como criminalização dos sujeitos, na medida em que lhes captura os filhos, bem como impede a possibilidade de um reencontro. Poderíamos levantar a seguinte questão: por que uma política aos usuários de crack, que também esteja direcionada aos seus filhos, não poderia ser pensada em termos de reabilitação e reencontro/retorno? Quem está ganhando com a separação irreversível entre mãe e filhos? Tampouco podemos esquecer que essa política tem como um de seus efeitos, ou como uma de suas bases, a criminalização das classes populares na medida em que as mães dependentes que nascem em clínicas privadas não estariam sujeitas a captura de suas crianças da mesma maneira.

Ao que tudo indica, há uma ausência de criatividade na formulação de políticas públicas; como se as velhas hierarquias e os velhos modelos nunca tivessem realmente sido velhos, já que permanecem presentes, atualizados no cotidiano dos sujeitos de diferentes formas. Por um lado, o Estado implementaria uma reparação aos sujeitos pelas políticas de isolamento do passado e o seu modelo 
autoritário e contrário aos direitos humanos básicos. De outro lado, esse mesmo Estado efetivaria uma política que se fundamenta em concepções autoritárias, contrárias a todos os princípios de justiça social e bem-estar.

Será que não existem outras experiências, de outros momentos ou de outros lugares, em torno dos usuários de drogas que possam nos tirar desse modelo e nos levar em direção a um futuro menos violento e onde os sujeitos possam gozar de seus direitos básicos de cidadania? Ou, tal como sugeriram duas antropólogas vinte anos atrás acerca dos direitos humanos, optaremos em seguir vivendo em um mundo onde uns são mais humanos do que outros? ${ }^{15}$ Precisamos começar a realizar novas escolhas, escolhas novas.

Notas

\begin{abstract}
'Naquele momento, essa doença era conhecida como lepra. Em maio de 1976, através da Portaria no165, o Ministério da Saúde tornou oficial a nova terminologia, substituindo o termo lepra e seus derivados pelo termo hanseníase e seus derivados. O novo termo, uma homenagem a Armauer Hansen, médico ao qual se atribui o descobrimento do bacilo Mycobacterium leprae, tem sido adotado em diferentes países e no Brasil é visto como uma das principais estratégias na luta contra o estigma associado ao termo anterior. Em 1995, o Congresso Nacional transformou aquela portaria na lei $n$ ㅇ 9.010 proibindo definitivamente o termo lepra no Brasil.
\end{abstract}

ii Afim de preservar a identidade dos sujeitos, todos os nomes foram modificados.

\title{
Referências
}

${ }^{1}$ Pandya S. The first international leprosy conferency, Berlin, 1897: the politics of segregation. Hist ciênc saúdeManguinhos.2003;10(1): 161-177.

${ }^{2}$ Gussow Z. Leprosy, Racism and Public Health: Social Policy in Chronic Disease Control. Boulder: Westview Press, 1989.

${ }^{3}$ Resenha de: Obregón-Torres D. Batallas contra la lepra: Estado, medicina y ciência en Colômbia. Medellín: Fondo Editorial, 2012.19(3): 815-84.

${ }^{4}$ Cruz A. O Hospital-Colónia Rovisco Pais: a última leprosaria portuguesa e os universos contingentes da experiência e da memória. Hist ciênc saúde-Manguinhos. 2009; 16 (2): 407-431.

${ }^{5}$ Curi L. Excluir, isolar e conviver: um estudo sobre a lepra e a hanseníase no Brasil. [Tese] Belo Horizonte: Universidade Federal de Minas Gerais; 2010.

${ }^{6}$ Maricato, G. Atingidos pela hanseníase, reparados pelo Estado: as múltiplas histórias performadas da lei 11.520/2007. [Dissertação] Porto Alegre: Universidade Federal do Rio Grande do Sul; 2015.

${ }^{7}$ Projeto de Lei no 2.962, de 2011. Altera a Lei no 11.520 de 18 de setembro de 2007, para conceder pensão especial aos filhos separados dos genitores atingidos pela hanseníase, isolados e internados compulsoriamente.

${ }^{8}$ Schuch P. A vida social ativa da ética na antropologia. Ver Bras Informação Bibliográfica Ciências Sociais. 2011; 71:5-24.

${ }^{9}$ Víctora C. Ética de pesquisa em equipe multidisciplinar. In: Victora C, Oliven R, Maciel M, Oro A. Antropologia e ética: o debate atual no Brasil. Niteroi: Editora da Universidade Federal Fluminense; 2004. P. 83-88.

${ }^{10}$ Fonseca C, Maricato G. Criando comunidade: emoção, reconhecimento e depoimentos de sofrimento. Interseções. 2013; 15: 252-274. 
${ }^{11}$ Penchaszadeh V, Schuler-Faccini L. Genetics and human rights. Two histories: Restoring genetic identity after forced disappearance and identity suppression in Argentina and after compulsory isolation for leprosy in Brazil. Genetics Molecular Biology 2014; 37 (1): 299-304.

${ }^{12}$ Fonseca C, Biondi F, Maricato G, Schuler-Faccini L. Project Reencontro: ethical aspects of genetic identification in families separated by the compulsory isolation of leprosy patients in Brazil. Journal Community Genetics. 2015; 6:215-222.

${ }^{13}$ Biondi F. Projeto Reencontro: identificação genética em famílias separadas pelo isolamento compulsório da hanseníase no Brasil. Porto Alegre. [Tese] Porto Alegre: Universidade Federal do Rio Grande do Sul; 2016.

${ }^{14}$ Flores T. Hanseníase e crack; controvérsias da internação compulsória no Brasil. Anais do 6 Abramd, 2007; Minas Gerais, Brasil.

${ }^{15}$ Fonseca C, Cardarello A. Direitos dos mais e menos humanos. Horizontes Antropológicos. 1999; 5(10): 83-121. 